\title{
Mechanisms of transcriptional regulation and prognostic significance of activated leukocyte cell adhesion molecule in cancer
}

\author{
Judy A King ${ }^{1,2+}$, Fang Tan ${ }^{3 \dagger}$, Flaubert Mbeunkui ${ }^{2}$, Zachariah Chambers ${ }^{1}$, Sarah Cantrell ${ }^{1}$, Hairu Chen ${ }^{1}$, \\ Diego Alvarez ${ }^{1}$, Lalita A Shevde ${ }^{4}$, Solomon F Ofori-Acquah ${ }^{2,3^{*}}$
}

\begin{abstract}
Background: Activated leukocyte cell adhesion molecule (ALCAM) is implicated in the prognosis of multiple cancers with low level expression associated with metastasis and early death in breast cancer. Despite this significance, mechanisms that regulate ALCAM gene expression and ALCAM's role in adhesion of pre-metastatic circulating tumor cells have not been defined. We studied ALCAM expression in 20 tumor cell lines by real-time PCR, western blot and immunochemistry. Epigenetic alterations of the ALCAM promoter were assessed using methylation-specific PCR and bisulfite sequencing. ALCAM's role in adhesion of tumor cells to the vascular wall was studied in isolated perfused lungs.

Results: A common site for transcription initiation of the ALCAM gene was identified and the ALCAM promoter sequenced. The promoter contains multiple cis-active elements including a functional p65 NF- $\kappa \mathrm{B}$ motif, and it harbors an extensive array of $\mathrm{CpG}$ residues highly methylated exclusively in ALCAM-negative tumor cells. These $\mathrm{CpG}$ residues were modestly demethylated after 5-aza-2-deoxycytidine treatment. Restoration of high-level ALCAM expression using an ALCAM CDNA increased clustering of MDA-MB-435 tumor cells perfused through the pulmonary vasculature of ventilated rat lungs. Anti-ALCAM antibodies reduced the number of intravascular tumor cell clusters.

Conclusion: Our data suggests that loss of ALCAM expression, due in part to DNA methylation of extensive segments of the promoter, significantly impairs the ability of circulating tumor cells to adhere to each other, and may therefore promote metastasis. These findings offer insight into the mechanisms for down-regulation of ALCAM gene expression in tumor cells, and for the positive prognostic value of high-level ALCAM in breast cancer.
\end{abstract}

\section{Background}

ALCAM/CD166 is an immunoglobulin cell adhesion molecule expressed by neuronal, endothelial, hematopoietic and epithelial cells [1-13]. It's up-regulation in cancer was first identified at the RNA level in melanoma cell lines as memD [14]. Subsequently, increased ALCAM expression was found in melanoma tumors in situ $[13,15]$. More widespread deregulation of ALCAM expression has since been reported in several other tumors including those of the prostate $[16,17]$,

\footnotetext{
* Correspondence: soforia@emory.edu

+ Contributed equally

${ }^{2}$ Center of Excellence in Healthy Communities, University of South Alabama,

307 N. University Boulevard, Mobile, AL 36688, USA

Full list of author information is available at the end of the article
}

esophagus [18], colon [19], bladder [20] and pancreas [21]. Alterations in ALCAM expression in tumors have recently been reviewed by Ofori-Acquah and King [22].

In a study of primary breast cancer tissues and nonneoplastic mammary tissue from the same mastectomies, we discovered that the level of ALCAM transcripts was lower in breast cancer tissues from patients who had metastases to regional lymph nodes [23], and that primary tumors from patients who died of breast cancer had significantly lower levels of ALCAM transcripts [23]. Subsequent studies showed that patients with the lowest level of ALCAM transcripts develop skeletal metastasis [24], that low ALCAM correlated with an aggressive tumor phenotype and significantly negative correlation between ALCAM expression and tumor 
diameter and grade [25]. More recently high-level ALCAM in breast cancer tissues has emerged as a predictor of good outcome among patients treated with tamoxifen [26] and adjuvant chemotherapy [27,28].

Tumor cells circulate in blood as single entities and multi-cellular emboli [29], and form secondary colonies in the vascular wall. This mechanism of metastasis is supported by evidence showing that tumor cells perfused in isolated rat lungs attach to the endothelia wall with minimum extravasation, leaving the endotheliumattached cells as the seeds of secondary tumors [30]. Indeed, in primary tumors derived from subcutaneous injection of murine breast carcinoma cells in immunocompromised mice, early metastatic colonies are intravascular in origin [31]. That adhesion molecules tethered on tumor cell surfaces influence their colonization of the lung, and downstream metastatic processes, is supported by the finding that the loss of ALCAM at the cell surface confers a high risk for disease progression and mortality in nodal negative cases of breast cancer [26].

In this study, the ALCAM gene was cloned and functionally characterized in a panel of breast cancer and melanoma tumor cell lines, and the influence of ALCAM on homotypic tumor cell adhesion in the pulmonary vasculature investigated. Our findings provide new mechanistic insights on ALCAM that can be developed further to alter its negative influence in tumor cell progression.

\section{Results}

\section{ALCAM expression in tumor cells}

ALCAM mRNA is significantly reduced in primary breast tumors from patients with metastatic disease however the amount of ALCAM in breast cancer cells at metastatic sites remains poorly understood. In this study, ALCAM mRNA in sixteen breast cancer cell lines derived from metastatic breast cancer tumors in the brain, lymph node and the pleural cavity, and primary breast tumors in ductal epithelium were quantified by qRT-PCR. Most cell lines derived from pleural effusions (MB-157, MDA-MB-435, HCC1428, MDA-MB-453, MCF-7, MDA-MB-231 and SK-BR-3) expressed relatively low levels of ALCAM mRNA, while cells originating from the lymph node (HCC70, HCC1008 and BT549) expressed relatively high amounts of ALCAM mRNA (Fig. 1A). ALCAM mRNA was virtually not detectable in MDA-MB-435. Regarding melanoma, ALCAM mRNA was markedly elevated in most of the cell lines (LOX, C8161.9, MelJuso) in agreement with the increased expression in primary tumors (Fig. 1A). Figure 1B shows that ALCAM protein levels determined by western blot analysis showed good correlation with ALCAM mRNA in most tumor cells. Most notably we did not detect ALCAM protein in MDA-MB-435 and FEMX-I tumor cells (Fig. 1B). ALCAM was generally expressed at cell-cell contacts of confluent tumor cell cultures although cytoplasmic localization was also detected (Fig. 1C). These data indicate that ALCAM is variably expressed in breast cancer cell lines, with the lowest level of expression, predominantly in cells derived from distant metastatic sites.

\section{Structure of the ALCAM promoter and MRNA synthesis at the ALCAM gene locus}

The human ALCAM gene is located on the long arm of chromosome 3 [2], therefore we designed primers complimentary to a genomic clone of human chromosome 3 to amplify and sequence 1000 base pairs of a putative ALCAM promoter. Comparing this sequence with entries in the GenBank database identified several reference clones with complete identity to our clone, except for variations of two nucleotides at -154 (A/G) and -618 $(\mathrm{C} / \mathrm{T})$ (data not shown). Signal scan analysis revealed that $1 \mathrm{~Kb}$ ALCAM promoter contained one copy of a direct repeat, ATTATTATTA sequence, present in the Drosophila melanogaster genes encoding transcription factor IIB (TFIIB) and the TATA-box-binding protein (TBP) and no canonical TATA-box.

To identify the site of transcription initiation on the ALCAM gene, complimentary DNA (cDNA) was prepared from non-malignant human cell lines (MCF-12A) and amplified in two sequential PCR analyses using ALCAM-specific reverse primers, and 5'RACE forward primers (Fig. 2A). A single major band of approximately 400 bp was identified in the final nested PCR experiments (Fig. 2B, lane 3). This product was cloned into Tvectors and 20 clones isolated and sequenced. The sequencing data revealed the presence of four putative transcription start sites, located 500, 496, 379 and 349 upstream of the ALCAM translation start site (Fig. 2C). These putative transcriptional start sites had variable agreement with the initiator consensus $\mathrm{PyPyA}_{+1} \mathrm{NT} /$ ApyPy (where Py is pyrimidine), and RNA synthesis usually begins at the adenine $(+1)$. The site at -349 (CCAATA) most closely matched the initiator consensus, with a core sequence [CANT] for strong initiation, with a $\mathrm{T}$ at +3 and $\mathrm{A}$ at +1 , and surrounded by pyrimidines except at position +4 . Clones with this site of initiation were the most abundant (65\%) identified in our 5'RACE experiments.

\section{Functional analysis of the ALCAM promoter in tumor cells} Preliminary studies showed that DNA sequences upstream of -650 of the ALCAM gene drove expression of a promoter-less luciferase gene in a wide variety of cell types, and that this activity required an intact Sp1 element at -550 (data not shown). Transient activities of 


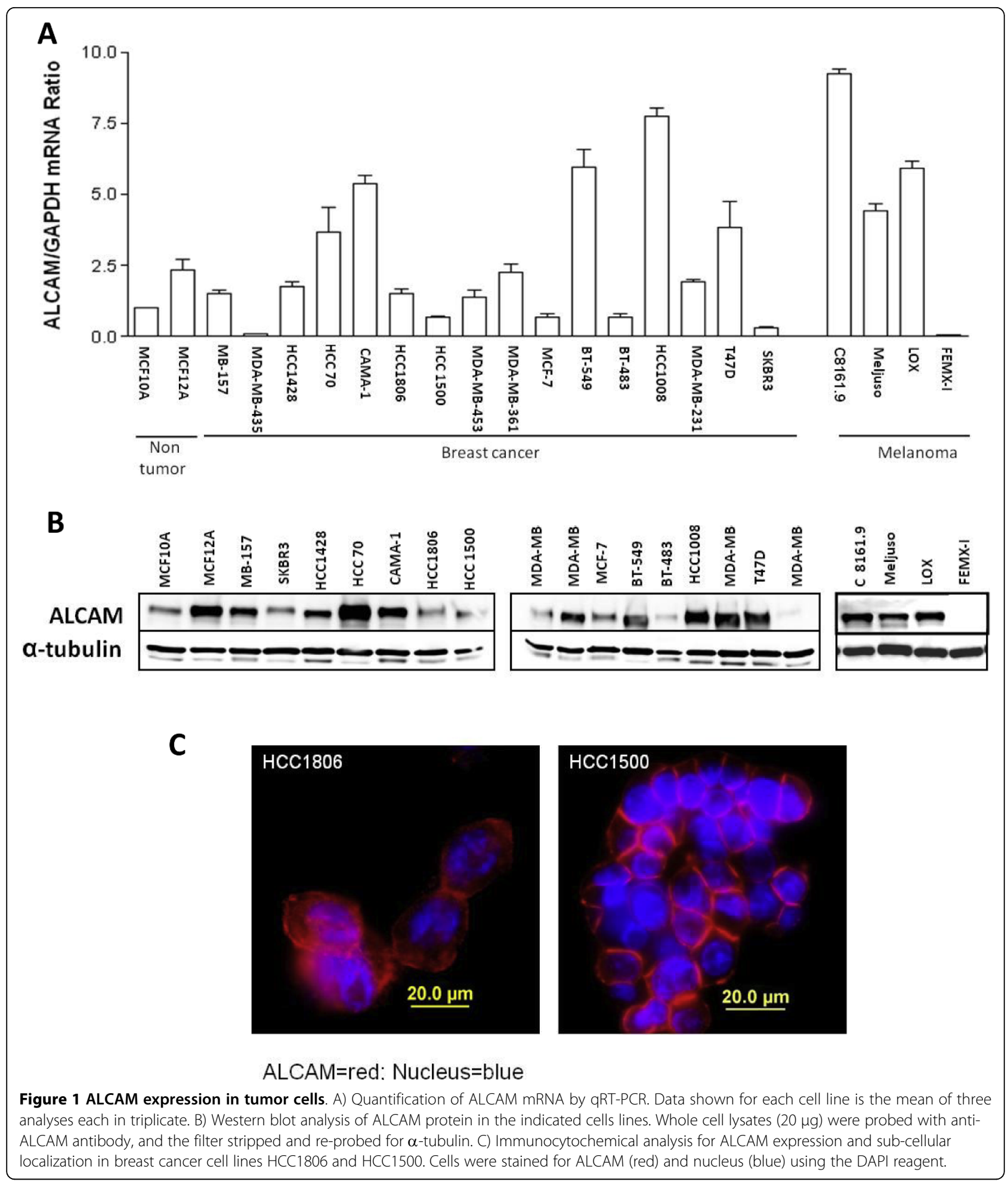

constructs p650, p800, p1000 and p1200 ALCAMLuc were virtually identical. Activity of p1200ALCAMLuc was 2-3-fold higher than of p1000ALCAMLuc (Fig. 3A) in three melanoma cell lines (C8161.9, LOX and Meljuso), which suggested the presence of a positive cis- acting element within the sequence between -1200 to -1000 . A putative NF- $\kappa \mathrm{B}$ sequence was identified at -1140 , this motif was mutated using site-directed mutagenesis (GGGGTTGCCC $\rightarrow$ GGAATTGCCC) to investigate its role in ALCAM promoter activity. This 


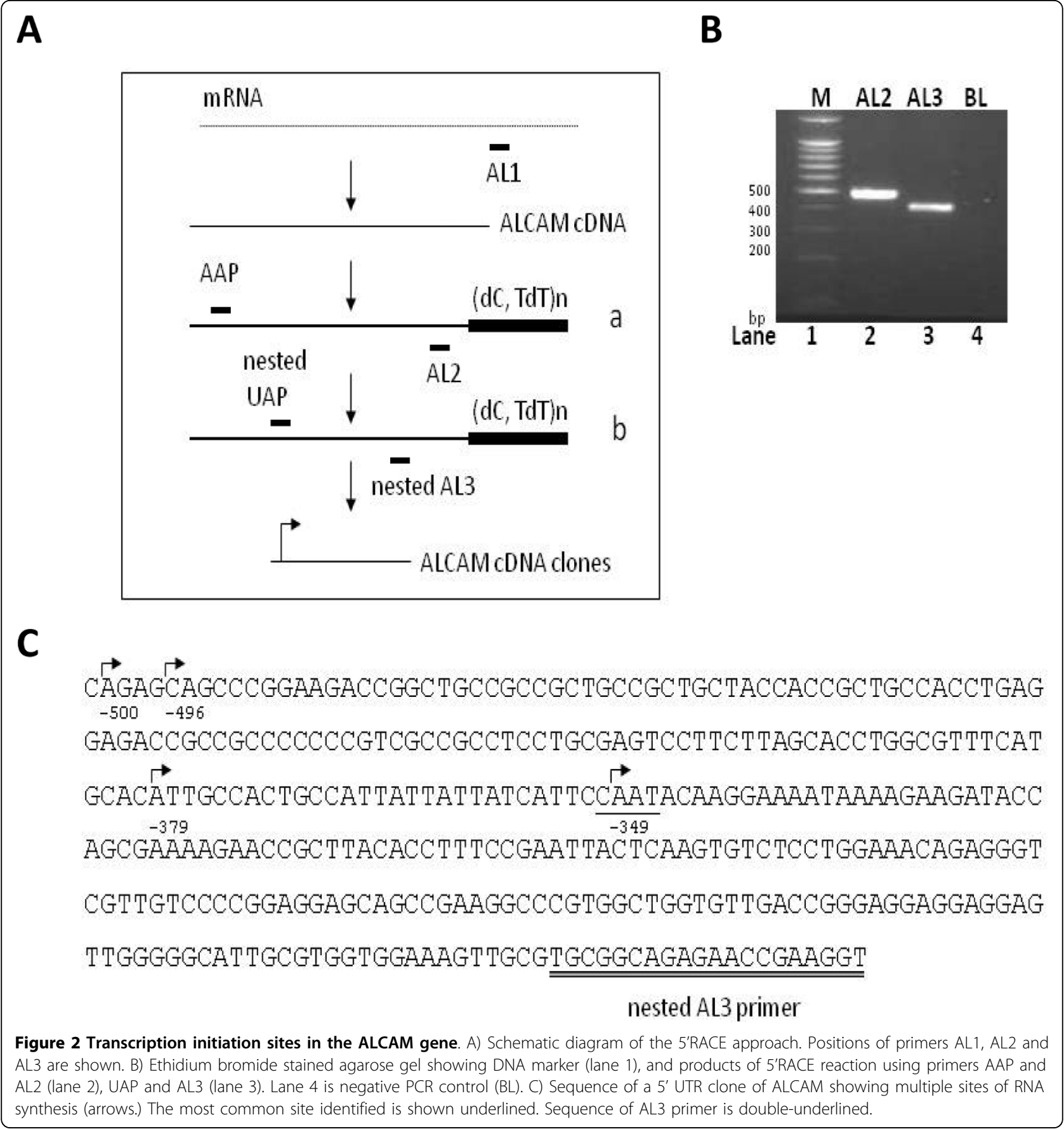

mutation reduced activity of the p1200 construct to the level found in the p1000 construct (Fig. 3B). We presumed that NF- $\kappa \mathrm{B}$ bound to this cognate element in the ALCAM promoter, and tested this hypothesis using a complement of in vitro and in vivo DNA-protein assays.

LOX cell nuclear extracts formed three unique complexes (B1, B2 and B3) of variable intensities with a biotin-labeled -1140 ALCAM NF- $\kappa$ B probe (Fig. 4A (i), lane 2). Competition with a 50 -fold molar excess of unlabeled wild-type probe abolished assembly of complex B2 and B3 (lane 3), while an unlabeled mutant probe with a 2-bp substitution of the NF- $\kappa \mathrm{B}$ consensus sequence (GGGGTTGCCC $\rightarrow$ GGAATTGCCC) had negligible or reduced impact on B2 and B3 complex formation (lane 4). Anti-p65 antibody markedly reduced the intensity of complex B2 (lane 5), and B3 to a moderate extent. CHIP analysis using anti-p65 antibodies confirmed occupancy of p65 on the endogenous ALCAM 


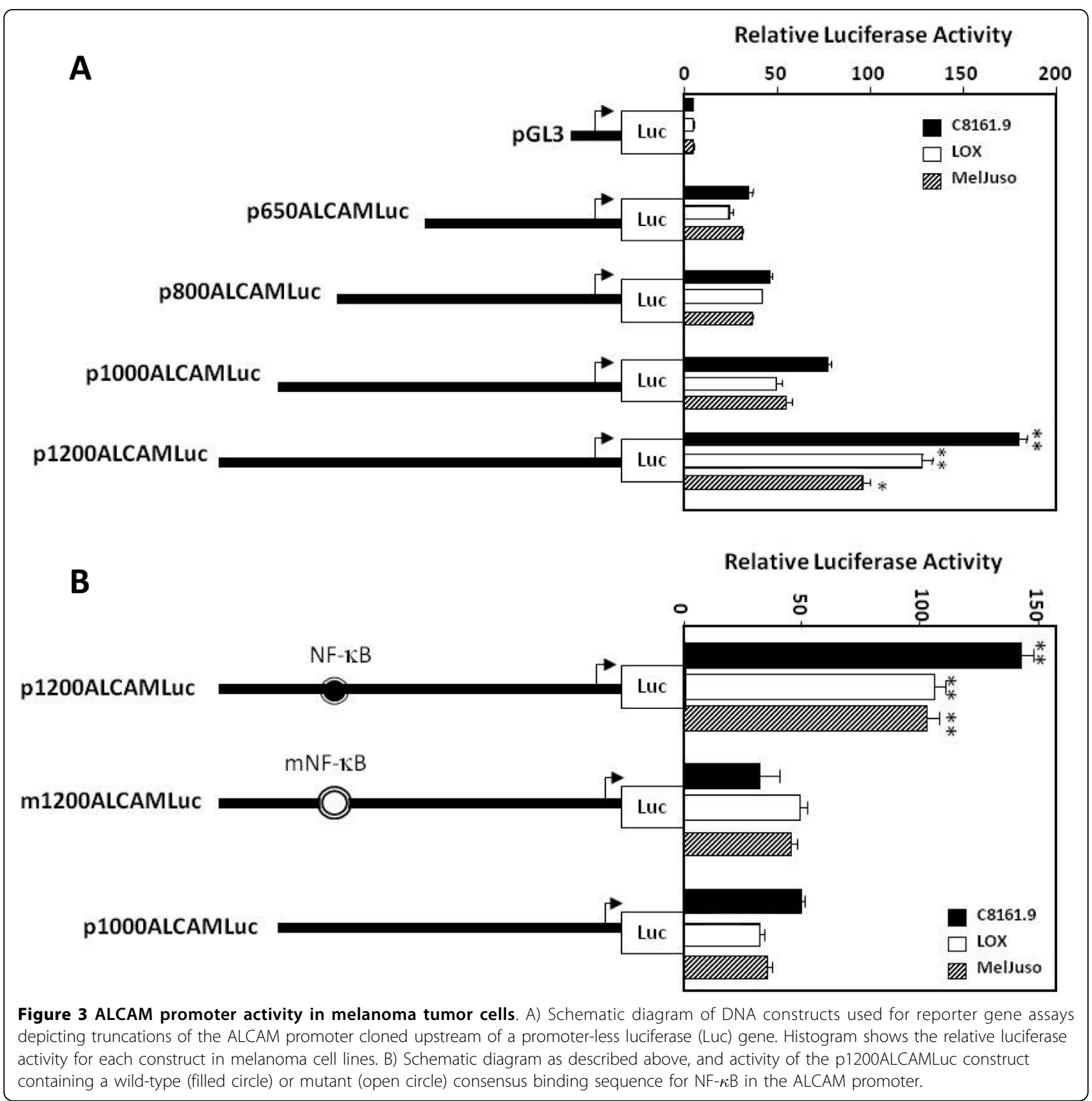

promoter in all three melanoma cell lines (Fig. 4A (ii), lanes 1-3). Collectively, these data show that protein complexes containing the $655 \mathrm{NF}-\kappa \mathrm{B}$ subunit bind to a cognate sequence at or around the -1140 element on the human ALCAM promoter. To validate these binding experiments, a DNA construct expressing NF- $\kappa \mathrm{B}$ (pCMV-65) was used in co-trans-activation assays, and this showed that co-transfection of $500 \mathrm{ng}$ p1200 ALCAMLuc with $100 \mathrm{ng}$ pCMV or pCMV-65 plasmid DNA significantly increased ALCAM promoter activity only in conjunction with the p65 expression vector (Fig.
4A (iii). We concluded from these data that NF- $\kappa$ B activates the human ALCAM promoter.

Next, we assessed the activity of various ALCAM promoter constructs truncated at $-650,-800,-1000$ and -1200 in breast cancer cells, and discovered no appreciable activity, even though these same cells supported high level activity of a CMV promoter driving a $\beta$-gal reporter gene (data not shown). We presumed this was likely due to the presence of negative regulatory elements and therefore assayed additional DNA constructs truncated at $-1400,-1800$ and -2600 . Activity of these 
A

i)

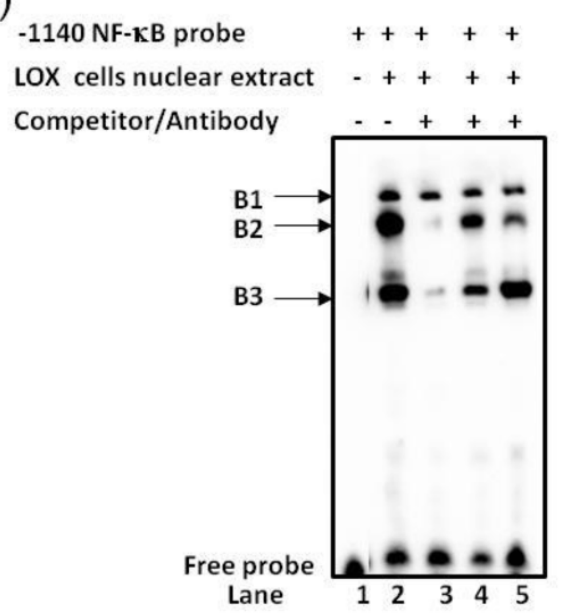

B

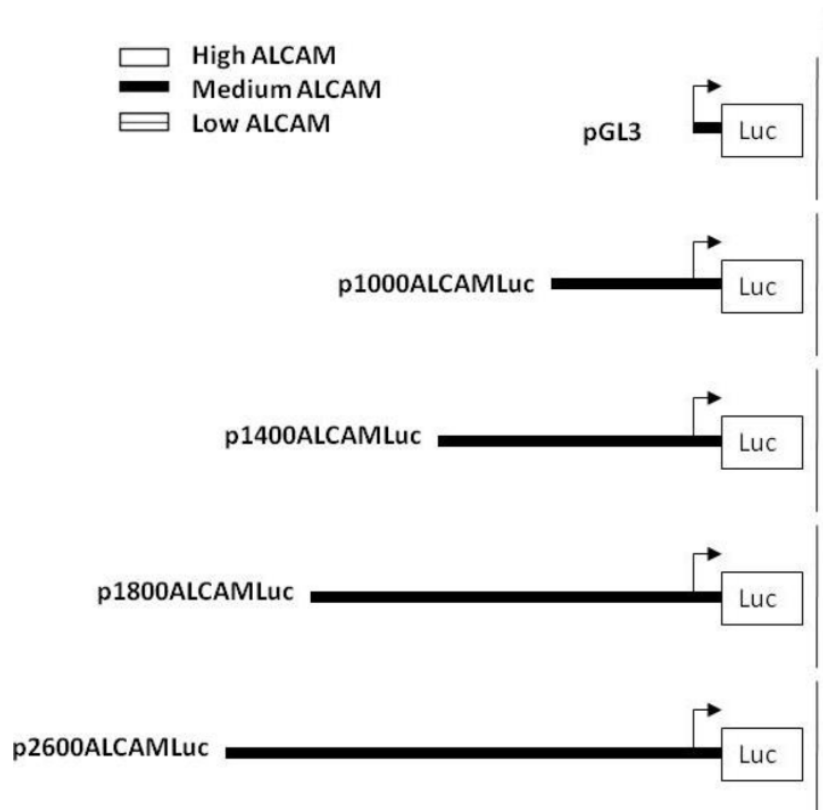

ii)

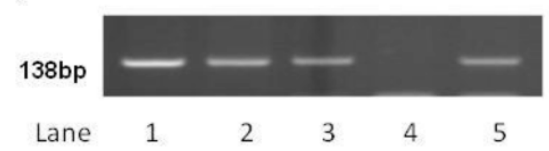

iii)

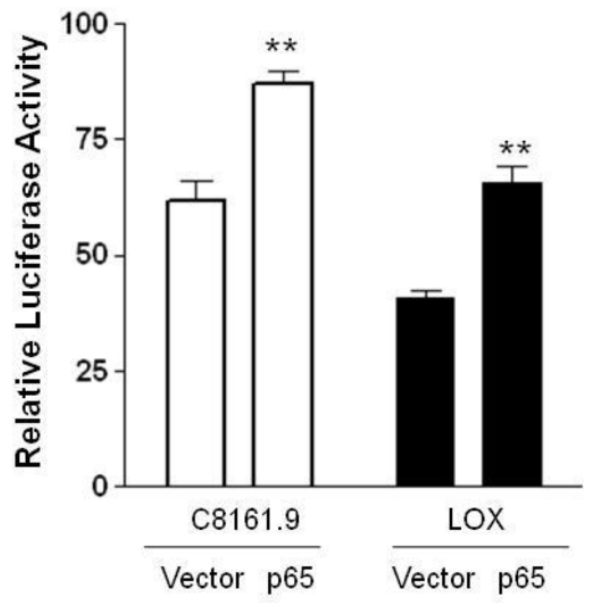

Relative Luciferase Activity
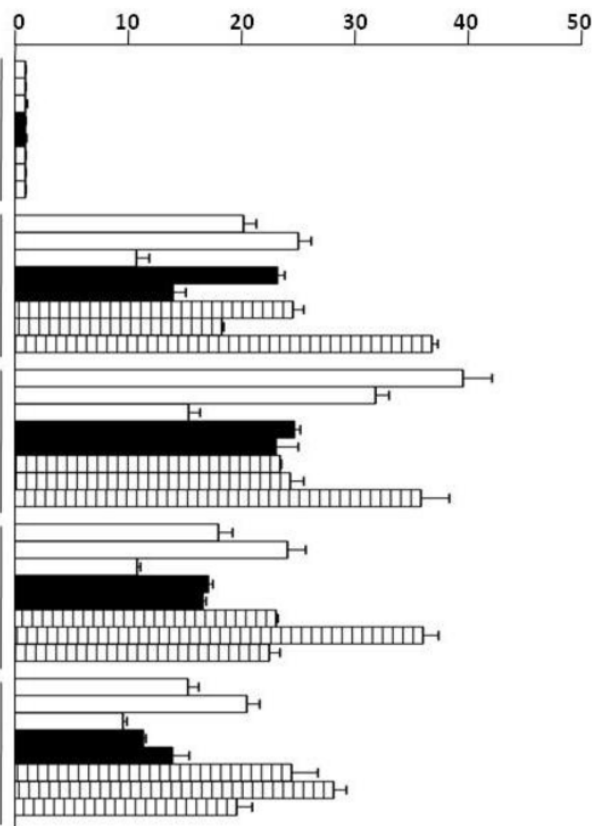

Figure 4 NF- $\kappa$ B binding to the ALCAM promoter and activity of the ALCAM promoter in breast cancer cell lines. A) p65 binding and trans-activation of the ALCAM promoter. (i) EMSA showing mobility of the $-1140 \mathrm{NF}-\kappa \mathrm{B}$ probe in the absence of nuclear extract (lane 1). Complexes B1, B2 and B3 form in the presence of LOX melanoma cell nuclear extracts (lane 2), subsequent lanes contain unlabelled wild-type NF- $\kappa$ B probe (lane 3), unlabelled mutant NF- $\kappa$ B probe (lane 4) and anti-p65 antibody (lane 5). (ii) ChIP assay showing PCR products for the -1140 ALCAM NF- $\kappa$ B motif and flanking DNA sequence amplified from chromatin of C8161.9 (lane1), LOX (lane 2) and Meljuso (lane3) cells precipitated with anti-p65 antibodies. Absence of PCR product in immunoprecipitation with non-immune lgG (lane 4), lane 5 (input DNA). (iii) Activity of p1200ALCAMLuc in C8161.9 and LOX cells over-expressing p65 or control vector. B) Schematic diagram of ALCAM reporter constructs and histogram showing relative luciferase activity for each in breast cancer cells with high (HCC70, MDA-MB-231, T47D), medium (BT549, CAMA-1) and low (HCC 1500, MCF-7,-SK-BR-3) ALCAM expression. 
larger promoter fragments remained relatively low in breast cancer cells irrespective of the level of ALCAM expression (Fig. 4B and data not shown).

\section{DNA methylation silences ALCAM expression in tumor cells}

Results from our reporter gene assays highlighted epigenetic modification as the basis for the lack of ALCAM expression in the MDA-MB-435 cell line. This idea was consistent with our sequencing data showing that the ALCAM promoter is GC-rich, and regulated by Sp1 (data not shown). To investigate this idea, genomic DNA from a large panel of breast cancer cells was modified by treatment with sodium bisulfite, and amplified using primers that discriminate methylated and unmethylated DNA (Fig. 5A). Unmethylated (U) DNA was specifically amplified in all breast cancer cell lines with detectable ALCAM expression, but not in the MDA-MB-435 cell line, which lacks endogenous ALCAM (Fig. 5A). Conversely, PCR product of methylated $(M)$ DNA was present only in reactions using MDA-MB-435 DNA (Fig. 5A). Sequencing of bisulfitemodified DNA revealed that virtually all CpG islands in the proximal ALCAM promoter were methylated in MDA-MB-435 tumor cells, with percentage methylation ranging from $15 \%$ to $60 \%$ (Fig. $5 \mathrm{~B}$ ). A similarly high degree of methylation was found in the FEMX-1 melanoma cell line (up to $75 \%$ of specific CpG residues), which also lacks ALCAM expression while all other tumor cells with appreciable ALCAM expression had a negligible (0-5\%) level of DNA methylation (Fig. 5B).

To directly confirm that CpG methylation silences the ALCAM gene, MDA-MB-435 cells were treated with 5aza-2-deoxycytidine which reduced methylation at each CpG site by 3 to $37 \%$ at concentrations of $5 \mu \mathrm{M}$ and 10 $\mu \mathrm{M}$ of the drug (Fig. 6A and data not shown). This modest degree of demethylation was accompanied by significantly increased ALCAM expression at both mRNA and protein levels in MDA-MB-435 cells (Fig. 6B). Collectively, these data identify CpG methylation of the ALCAM promoter as one mechanism for controlling ALCAM gene expression.

\section{ALCAM clusters tumor cells perfusing through an isolated rat lung}

The isolated ventilated perfused rat lung system has previously been used to investigate the fate of circulating tumor cells, and was employed here to test the influence ALCAM has on these cells. Stable transfection of an ALCAM-GFP construct conferred high level ALCAM expression in MDA-MB-435 cells, and importantly localized ALCAM to sites of cell-cell contact in confluent cultures (Fig. 7A). Perfusion of this clone into rat lungs caused congestion of tumor cells in the pulmonary vasculature, while relatively few cells were retained in experiments using a control clone expressing an empty vector (Fig. 7B). Quantitative analysis revealed more than 2-fold increase in the number of the ALCAM-positive MDA-MB-435 cells retained in the rat lung (Fig. 7C), compared to the ALCAM-negative variant. Pre-treating ALCAM-positive MDA-MB-435 cells with anti-ALCAM antibodies prior to perfusion significantly reduced the number of tumor cells in the rat lung (Fig. 7C). Additional control experiments showed that anti-ALCAM antibodies did not alter the total number of ALCAM-negative MDAMB-435 tumor cells retained in the rat lung.

\section{Anti-ALCAM antibody inhibits clustering of perfusing tumor cells}

Next, we focused on the mechanisms of retention of tumor cells in the lung by counting the number of intravascular tumor cell clusters and single tumor cells adherent to endothelial walls. ALCAM expression increased by 3-fold the number of MDA-MB-435 tumor cell clusters, while anti-ALCAM antibody reduced this number significantly (Fig. 7D). On the contrary, ALCAM expression had no significant impact on the number of single MDA-MB-435 tumor cells adhering to the endothelial wall, and anti-ALCAM antibody did not influence this number (Fig. 7E). These data indicate that the presence of ALCAM enhances retention of tumor cells in the pulmonary vasculature primarily as clusters of cells tightly adherent to each other, and not as individual cells adherent to the endothelium. Recent findings indicate that the parental MDA-MB-435 cell line is melonocytic in origin and may therefore exhibit adhesive behaviors atypical of breast cancer cells. To address this concern and also confirm our findings in cells endogenously expressing ALCAM, perfusion experiments were performed using MDA-MB-231. These highly-expressing ALCAM tumor cells formed several clusters while perfusing the pulmonary vasculature of the rat lung (Fig. 8A), two function blocking ALCAM antibodies consistently reduced significantly the total number retained in the rat lung, while IgG had no impact (Fig. 8B, C).

\section{Discussion}

Altered expression of the cell adhesion molecule ALCAM is associated with progression, metastasis and response to therapy in multiple cancers, yet specific DNA elements that regulate ALCAM promoter activity have not previously been defined. We found a consensus $\mathrm{NF}-\kappa \mathrm{B}$ element at -1140 and site-directed mutagenesis of this element significantly reduced ALCAM promoter activity. Over-expression of p $65 \mathrm{NF}-\kappa \mathrm{B}$ increased ALCAM promoter activity, while p65 occupied the cognate motif on the endogenous ALCAM promoter in melanoma cells lines (Fig. 4A ii). These data strongly 
A

-282 GGCTGCGGATCCGTGCTTCAACCACCTGCTTTGCGCTGCGTCCGGGGAAGTGGGGAGGAGACGGGAGGGA

-212 GGGAGGAGGCGGGGAGAGGAGGAAAGAGGCAGCTTACACACGCCTTCCA GTCCCTCTACTCAGAGCAGCC

-142 CGGAGACCGCTGCCGCCGCTGCCGCTGCTACCACCGCTGCCACCTGAGGAGACCCGCCGCCCCCCCGTCG

\section{$\mathrm{M}=$ methylated \\ $\mathrm{U}=$ unmethylated}

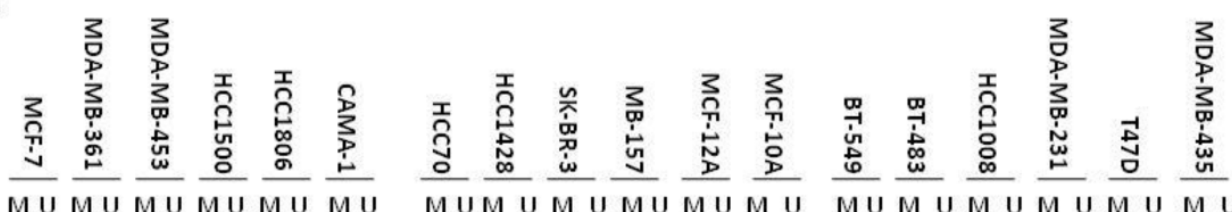

Primers:
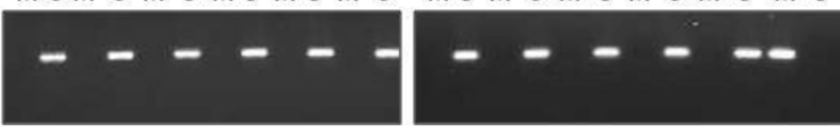

B
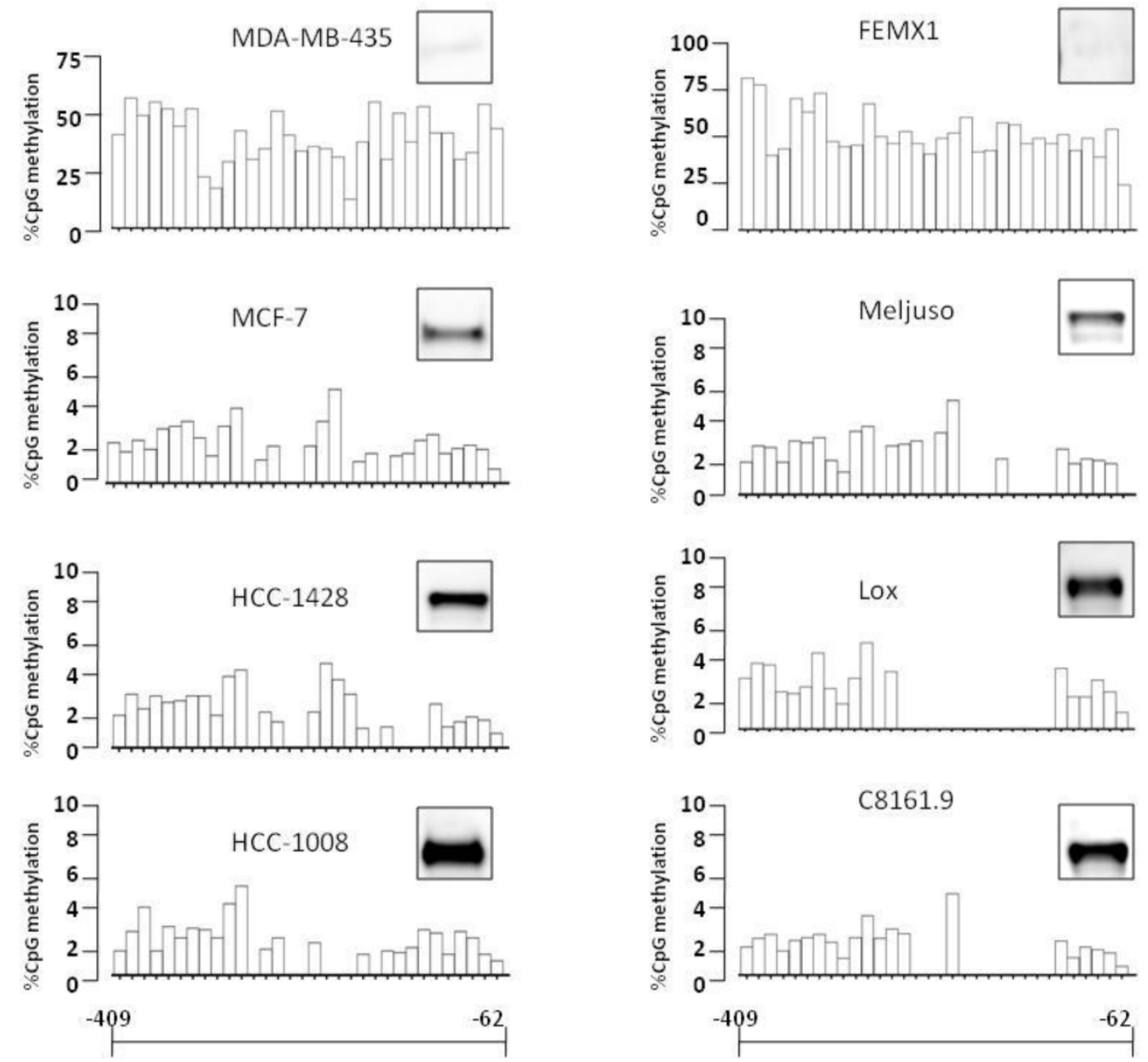

Figure 5 Promoter methylation regulates ALCAM expression in tumor cells. A) Sequence of the proximal ALCAM promoter showing multiple CpG islands (in bold) and methylation-specific primer targets (underlined). Ethidium bromide stained agarose gel showing PCR products for unmethylated $(U)$ and methylated (M) genomic DNA. B) CpG methylation profile of the ALCAM promoter in the interval -62 and -409 relative to the cap site as determined by pyrosequencing for the indicated breast (MDA-MB-435, MCF-7, HCC-1428, HCC-1008) and melanoma (FEMX-1, MelJuso, LOX, C8161.9) tumor cells. ALCAM protein detected by western blot analysis is shown for each cell line. Note that the maximum value on the \%CpG methylatyion axis (y) for the ALCAM-negative tumor cells MDA-MB-435 and FEMX1 are $75 \%$ and $100 \%$ respectively, and $10 \%$ for cells with endogenous ALCAM expression. 


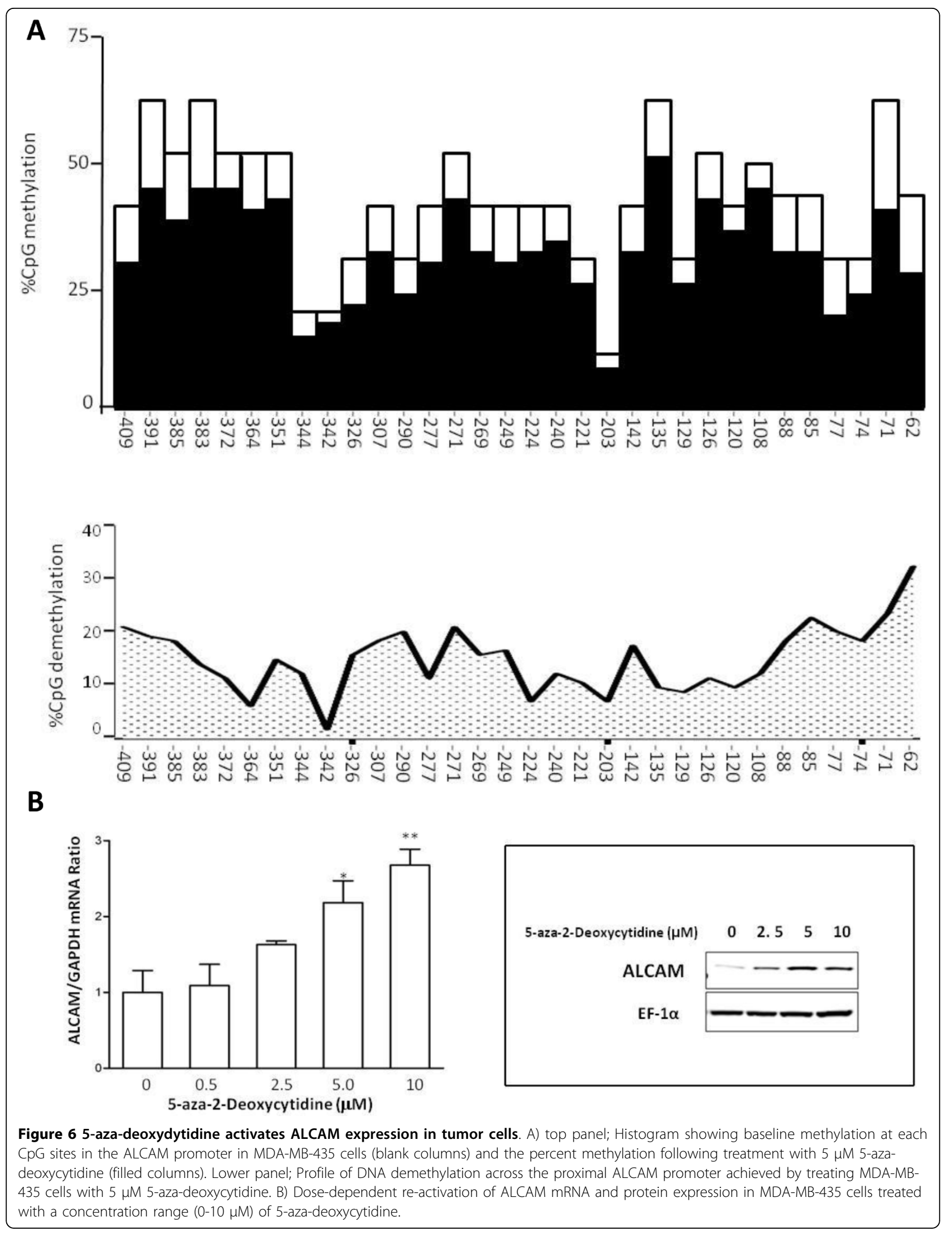




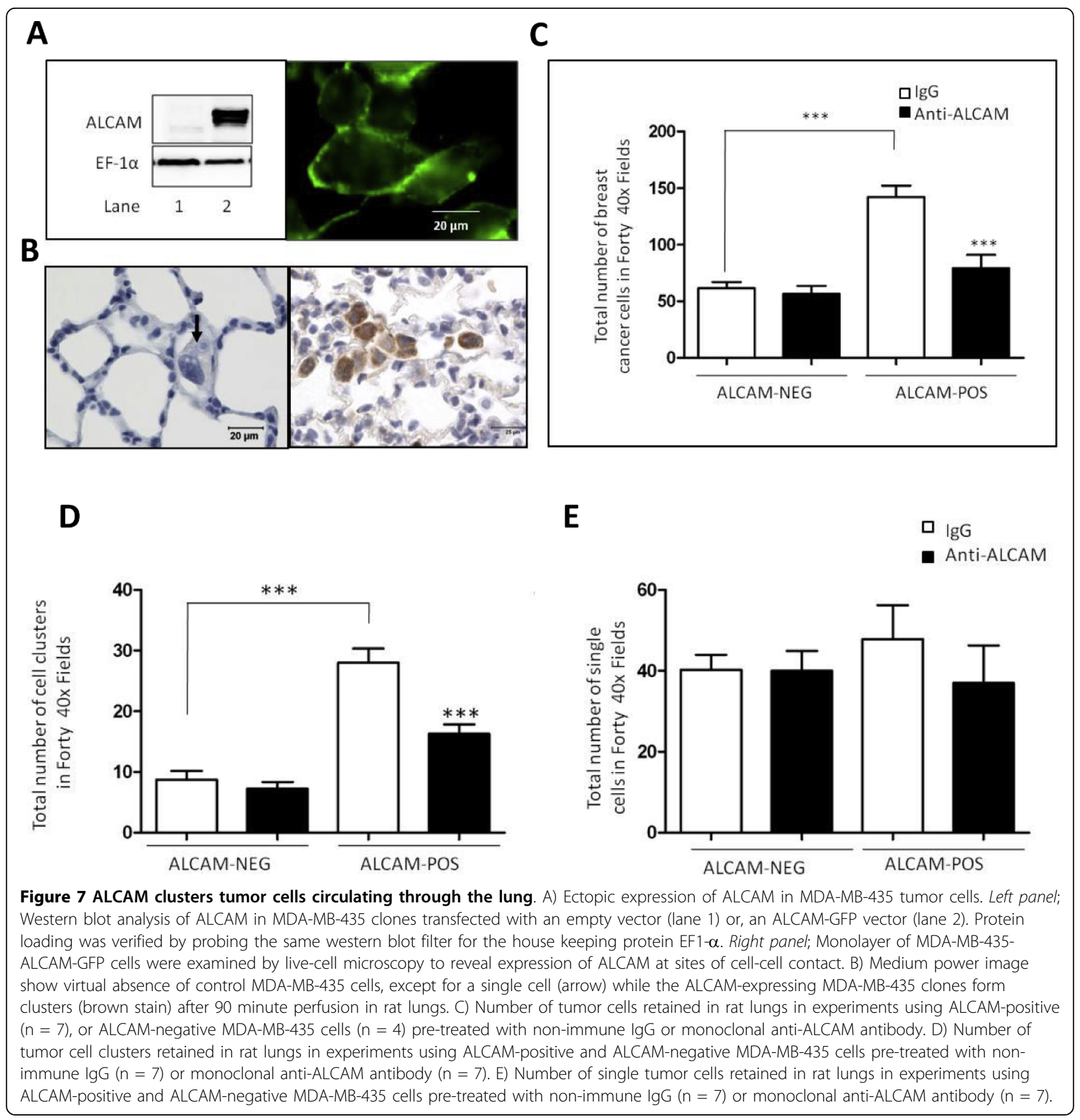

suggests that ALCAM is a target of the NF- $\kappa$ B pathway. Our data in melanoma cells is consistent with previous reports showing that transformation of avian lymphoma B-cells with $v$-rel induces ectopic expression of ALCAM [32]. Mutations of cell cycle genes activate NF- $\kappa$ B, which in turn is directly responsible for increasing expression of several target genes involved in melanogensis [33-36]. Given the marked elevation of expression of ALCAM in vertically growing primary melanoma tumors, it is likely that the ALCAM gene locus is a downstream target of NF- $\kappa \mathrm{B}$ in melanoma. Our reporter gene analysis did not reveal cis-active elements in the ALCAM promoter that suppress ALCAM expression in breast cancer cell lines. However, the human ALCAM gene locus is relatively large [37] and may contain negative regulatory elements far upstream of the transcription start site, where they may influence gene expression, via long-range DNA looping.

Epigenetic modification of DNA is a well established mechanism for suppressing genes, and we discovered 
A

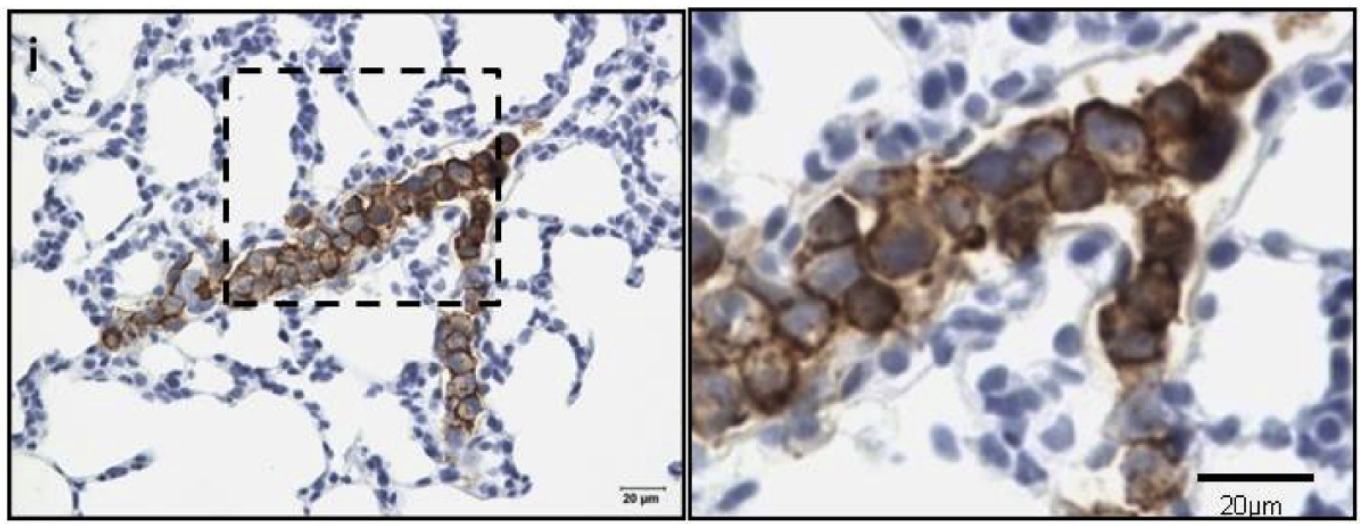

B

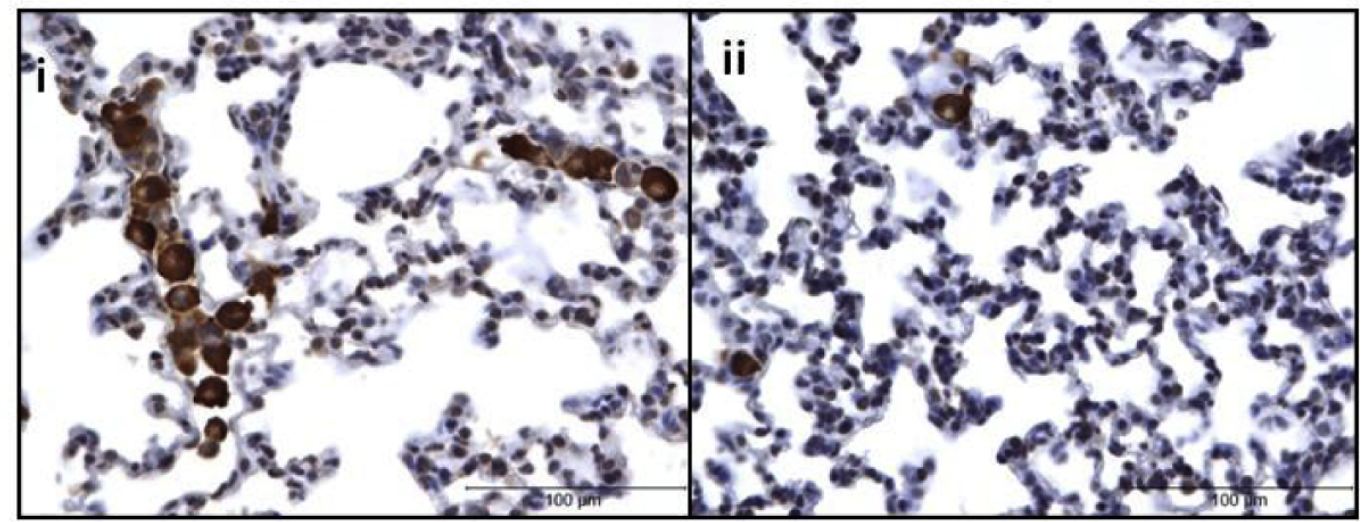

C
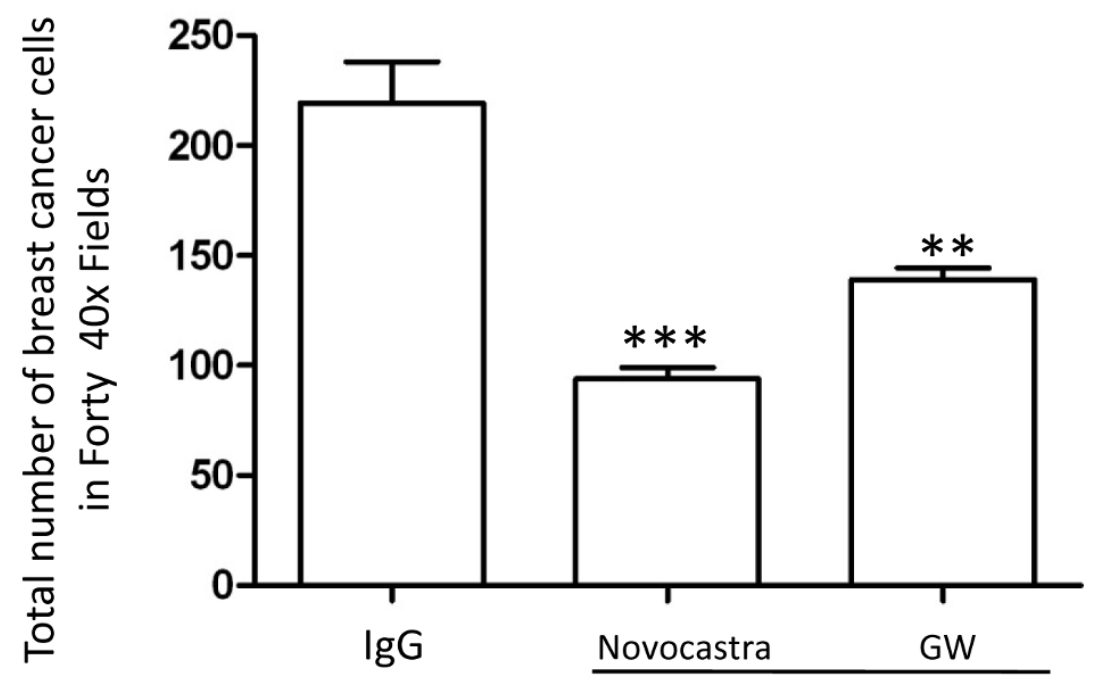

Anti-ALCAM antibodies

Figure 8 Anti-ALCAM antibodies reduce clustering of tumor cells circulating through the lung. A) (i) Medium power image of a rat lung section show MDA-MB-231 tumor cells logged in a medium-size vessel, ii) magnified section of the area enclosed by the dotted box in (i). B) Low-power image of rat lung section show MDA-MB-231 tumor cells in experiments with non-immune lgG (i) or anti-ALCAM antibody (ii). C) Number of tumor cells retained in isolated perfused rat lungs following incubations with non-immune $\lg (n=11)$ and Novocastra $(n=4)$ and GW $(n=7)$ monoclonal anti-ALCAM antibodies. 
that the proximal ALCAM promoter is endowed with multiple CpG islands, which are targets for DNA methylation (Fig. 5A). Sequencing revealed that virtually all CpG islands in the ALCAM promoter are methylated in tumor cells lacking ALCAM expression. The plasticity of this modification, and its inherent linkage to gene expression was confirmed in experiments with 5-azadeoxycytidine (Fig. 6A, B). Additional correlative data in both breast cancer and melanoma cell lines showed direct relationship between the level of DNA methylation of the ALCAM promoter and ALCAM protein level (Fig. 5B). 5-Aza-deoxycytidine is currently in clinical use, and may be indicated to boost ALCAM expression in breast cancer [38], however, it also alters expression of a large number of genes $[39,40]$. Moreover, our data suggests this drug alone maybe insufficient to fully restore ALCAM expression in tumors with severely repressed ALCAM expression. The level of ALCAM expression is variable in different tumor types. This heterogeneity can be resolved by the unique tissue origins of different tumors, although variable expressions have been described at different stages of tumor development in the same type of malignancies. With respect to breast cancer, multiple studies have examined ALCAM expression at the transcript and protein levels, using a variety of methods. There is an emerging consensus that low level ALCAM is a bad prognostic marker in breast cancer $[23,24,27,41-44]$. In the largest, and most recent study, Ihnen et al found that low ALCAM mRNA was associated with shorter disease free survival and duration of survival in hierarchical cluster analysis involving training and multiple validation cohorts of breast cancer patients [44]. This emerging paradigm is supported by the correlations of high ALCAM mRNA with progesterone and estrogen receptor status, better response and longer overall survival. It is reasonable to presume that down-regulation of ALCAM activates alternative compensatory pathways. Plausible candidates are other ALCAM isoforms, such as soluble ALCAM, which may account for the elevation of serum ALCAM in patients with breast cancer [45]. A similar mechanism may explain the marked increased in cytoplasmic ALCAM in some aggressive breast cancer tissues [26]. While the relationships between these various deregulations of ALCAM expression remain to be verified, they all represent loss of function of ALCAM, which to date has consistently been associated with poor prognosis in breast cancer.

Alteration of adhesion molecule expression is a hallmark of several cancers [46], however the underlying biological mechanism for the deleterious effects of reduced ALCAM in breast cancer is poorly defined. In this study, we examined the impact of ALCAM on the adhesive behavior of tumor cells in the pulmonary vasculature using the isolated rat lung system. Experiments using two function blocking ALCAM antibodies, and genetically-modified MDA-MB-435 clones ectopically expressing ALCAM, revealed that ALCAM promotes homotypic tumor cell adhesion demonstrated by clusters of tumor cells in the pulmonary vasculature. ALCAM is localized at sites of lateral cell contacts in the pulmonary endothelium, and is therefore unlikely to mediate adhesions between circulating tumor cells and the endothelium [47]. Colonization of the lung by tumor cells involves their interaction with the endothelial wall, and subsequent extravasations. The data reported here suggests that ALCAM is likely to slow down this process, by promoting homotypic tumor cell adhesion. This idea is pertinent to the level of ALCAM expression and the metastatic phenotypes of the two tumor cells lines we used in our lung perfusion experiments. The ALCAM-positive MDA-MB-231 cells which formed large cell clusters in the rat lung cannot metastasize to distant sites when injected into the mammary fat pad of athymic nude mice $[48,49]$. On the contrary, ALCAM-negative MDA-MB-435 efficiently and spontaneously forms distant metastasis under identical experimental conditions [48-51]. Additional mechanistic studies are needed to clearly define the relationship between ALCAM level and the metastatic phenotypes of tumor cells. In this study, we have shown that loss of ALCAM function in MDA-MB-231 and gain of ALCAM function in MDA-MB-435, switches their adhesive phenotypes in the pulmonary vasculature, a process that influences metastasis to the lung [30,31].

\section{Conclusions}

The ALCAM promoter is extensively methylated in tumor cells that lack ALCAM expression. Using genetic and antibody blocking assays we demonstrate that ALCAM enhances homotypic adhesion of tumor cells perfusing through the pulmonary vasculature. Thus, reduced homotypic tumor cell adhesion may explain why low-level ALCAM is a risk factor for metastasis and early death in breast cancer. Therapeutic strategies that re-activate ALCAM expression in breast cancer tumors may slow-down tumor metastasis and improve survival.

\section{Methods \\ Cells}

Cells studied included MDA-MB-435, originally classified as of breast cancer origin, but recently shown to posses melanocytic lineage, fifteen breast cancer (BT549, BT483, MDA-MB-231, HCC70, HCC1428, HCC1806, MDA-MB-453, MCF-7, CAMA-1, MB-157, MDA-MB361, HCC1500, HCC1008, T47D and SK-BR-3) and two normal epithelial breast cell lines (MCF-10A and MCF- 
12A) purchased from American Type Culture Collection (ATCC, Rockville, MD). In addition, four melanoma cell lines (FEMX-I, LOX, MelJuso, C8161.9) were studied. All cell lines were cultured using media conditions recommended by the commercial or academic suppliers. Cells were incubated at $37^{\circ} \mathrm{C}$ in a humidified chamber with $5 \% \mathrm{CO}_{2}$ (except for MDA-MB-361, which was cultured in room air). MDA-MB-435 cells $\left(2 \times 10^{5}\right.$ per 35 $\mathrm{mm}$ well) were plated overnight, and then treated with a concentration range $(0-10 \mu \mathrm{M})$ of 5-aza-2-deoxycytidine (EMD, Madison, WI). Cells were replenished with fresh medium containing 5-aza-2-deoxycytidine every 48 hours for six days, and harvested for analysis.

\section{Western Blots}

Cell lysates $(20 \mu \mathrm{g})$ were resolved on a 10\% SDS-PAGE. Proteins were transferred to PVDF membrane and probed with antibodies (ALCAM/CD166, Novocastra Laboratories) and secondary antibody conjugated to horseradish peroxidase and detected using chemiluminescence (Pierce Biotechnology; Rockford, IL).

\section{Quantitative RT-PCR and 5' RACE}

Total RNA was extracted using RNeasy Mini Kit (Qiagen, Valencia, CA) and converted to cDNA from $2 \mu \mathrm{g}$ total RNA by SuperScript RT II (Invitrogen, Carlsbad, CA). Quantitative RT-PCR was performed using an ABI StepOnePlus analyzer (Applied Biosystems, Foster City, CA) with SYBR Green master mixture containing primers for ALCAM (NM_001627) or GAPDH (Additional file 1: Table S1). The start of RNA synthesis was identified using the rapid amplification of cDNA ends (RACE) approach (5'RACE, Invitrogen). Briefly, ALCAM cDNA was synthesized from $3 \mu \mathrm{g}$ RNA using SuperScript RT II and ALCAM-specific primer AL1 (Additional file 1: Table S1), and purified using SNAP column (Invitrogen), tailed with $\mathrm{TdT}$ and amplified by PCR using abridged anchor primer (AAP) and ALCAMspecific primer AL2. PCR product was amplified using a nested ALCAM-specific primer AL3 and universal amplification primer (UAP), cloned into a $\mathrm{T}$-vector and sequenced.

\section{DNA constructs and stable cell lines}

Human genomic DNA was amplified by PCR using a common reverse primer and various forward primers truncated at $-2600,-1800,-1400,-1200,-1000,-800$, $-650,-400$ and -200 (Additional file 1: Table S1). PCR products were cloned into a promoter-less luciferase vector (pGL3, Promega, Madison, WI) via Mlu I and $B g l$ II, and verified by DNA sequencing. We have previously described construction of a fusion DNA vector expressing ALCAM and enhanced green fluorescent protein (GFP) [47]. ALCAM-GFP and control GFP vector
(Applied Vironomics, Fremont, CA) were transfected into log-phase growing MDA-MB-435 cells using lipofectamine 2000 (Invitrogen). Stable lines of MDA-MB435-ALCAM-GFP and MDA-MB-435-GFP were selected using G418 $(500 \mu \mathrm{g} / \mathrm{ml})$.

\section{Reporter assays}

Cells $\left(8 \times 10^{4}\right)$ were seeded in 24-well tissue culture plates and co-transfected with ALCAM promoter luciferase plasmids (800 ng) and pcDNA3.1/His/LacZ (100 ng) (Invitrogen) plasmid DNA using lipofectamine 2000. Twenty-four hours after transfection cell lysates were prepared and the activities of luciferase (Firefly-Luciferase Reporter Assay System, Promega) and $\beta$-galactosidase (Galacto-Star system, Applied Biosystems) determined using the Veritas Luminometer (Turner Biosystems, Sunnyvale, CA). Luciferase activity was normalized to the activity of $\beta$-galactosidase, and the relative luciferase activity for test constructs calculated by assigning the normalized luciferase activity of the promoter-less pGL3 construct as 1.0. Minimum of three independent experiments was performed for each reporter each in triplicate.

\section{Electrophoretic mobility shift assay}

In vitro protein-DNA interaction was examined using the LightShift Chemiluminescent electrophoretic mobility shift assay (EMSA) kit (Pierce). ALCAM-specific EMSA DNA probes were synthesized, gel purified and biotin labeled (Additional file 1: Table S1). Nuclear extract $(4 \mu \mathrm{g})$ was combined with biotin-labeled DNA probes in binding buffer containing $50 \mu \mathrm{g} / \mathrm{ml}$ poly $(\mathrm{dI}-$ dC). Fifty-fold molar excess of unlabelled DNA probe was added to the binding reaction in competition experiments. Anti-p65 NF- $\kappa$ B antibodies $(2 \mu \mathrm{g})$ (Santa Cruz) were added to the reaction mixture. Products of the binding reaction were resolved in 6\% DNA retardation gel, transferred to a nylon membrane and biotinlabeled complexes detected by chemiluminescence (Fujifilm LAS-1000 imaging system; FujiFilm, Valhalla, NY).

\section{Chromatin immunoprecipitation assay}

Protein-DNA cross-linking was performed by fixing 40 million cells with $1 \%$ formaldehyde. Nuclei was sonicated on ice in shearing buffer (ChIP-IT; Active Motif, Carlsbad, CA) to obtain chromatin fragments of 1001000 base pairs, which were pre-cleared with protein G beads (Salmon sperm DNA/Protein G agarose). Precleared chromatin was incubated with anti-p65 NF- $\kappa \mathrm{B}$ antibody (Santa Cruz) or non-immune IgG. Immune complexes were precipitated with protein $\mathrm{G}$ beads, and the eluate reversed cross-linked in $190 \mathrm{mM} \mathrm{NaCl}$. DNA was purified and amplified by PCR with specific ALCAM primers (Additional file 1: Table S1). 


\section{DNA methylation}

Genomic DNA was extracted using QIAamp DNA Mini Kit (Qiagen) and $1 \mu \mathrm{g}$ of this sample treated with sodium bisulfite (EZ Methylation Gold kit, Zymo Research, Orange, CA). Bisulfite-modified DNA (1 $\mu \mathrm{l})$ was amplified in two separate PCR reactions using primers flanking the interval -256 to -118 of the ALCAM promoter and specific for methylated and unmethylated genomic DNA (Additional file 1: Table S1). For bisulfite sequencing biotinylated reverse primers were used in two separate reactions to amplify two distinct and overlapping DNA fragments in the interval -409 to -62 . Biotin-labeled single-stranded PCR products were isolated and pyrosequenced (PSQ ${ }^{\mathrm{m}} 96 \mathrm{HS}$ System EpigenDx Biotage, Kungsgatan, Sweden). Methylation status of each CpG site was analyzed individually as T/C SNP using QCpG software (Biotage, Kungsgatan, Sweden).

\section{Isolated perfused lungs}

The isolated perfused ventilated rat lung was prepared as we have described previously [52,53]. Adult male Sprague-Dawley rats were anesthetized with pentobarbital sodium $(60 \mathrm{mg} / \mathrm{kg} \mathrm{ip})$, and a catheter was inserted into the trachea, and the lungs were mechanically ventilated. A median sternotomy was performed, and then heparin (60 units) was administered via the left ventricle and allowed to circulate for $3 \mathrm{~min}$. Catheters were placed and secured around the pulmonary artery and the left atrium. Rat lungs were perfused with Earle's balanced salt solution and $4 \%$ bovine serum albumin containing tumor cells at a density of 40,000 cells per $\mathrm{ml}$. In some experiments, tumor cells $\left(2 \times 10^{6}\right)$ were incubated for 1 hour with anti-ALCAM (1:20 Novocastra or 1:20 GW, GenWay Bioetech) or non-immune IgG (control) prior to perfusion. Tumor cells were perfused for 90 minutes followed by perfusion with Earle's balanced salt solution without tumor cells for 5 minutes.

\section{Immunostaining}

Breast cancer cells were fixed with methanol and blocked with $3 \%$ normal goat serum, followed by staining with 1/100 dilution of anti-ALCAM (Novocastra Laboratories Ltd), and Alexflour 594 goat anti-rabbit IgG (Molecular Probes, Eugene, Oregon). Nucleus was stained with DAPI (Molecular Probe). Cells were examined by epifluorescence (Nikon TE2000, Nikon Instruments Inc., Melville, NY). Lung tissue was fixed in $10 \%$ formalin or $4 \%$ paraformaldehyde, processed, embedded in paraffin, and sectioned (4-5 microns). Sections were stained with hematoxylin \& eosin (H\&E), anti-GFP (1:250; Molecular Probes, Inc., Eugene, OR), or anti-ALCAM (1:40; Novocastra Laboratories Ltd). Tumor cells in twenty $40 \times$ fields were counted on each section/slide. A total of forty lung fields $(40 \times)$ per rat lung were analyzed by light microscopy to assess for tumor cells. The number of tumor cells and presence of single cells or cell aggregates were recorded. Sections were photographed with a Nikon E600 light microscope with digital imaging (Nikon Instruments Inc., Melville, NY).

\section{Statistics}

The data are reported as the means \pm SE for at least three independent experiments. Data was graphed and analyzed using Prism software (GraphPad Software). Statistical analysis of the raw data was performed by two tailed $t$ tests. Differences were considered significant if $p$ value were $<0.05\left(^{(*)},<0.01{ }^{(* *}\right)$ and $\left.<0.001{ }^{(* * *}\right)$.

\section{List of Abbreviations}

ALCAM: activated leukocyte cell adhesion molecule; RACE: rapid amplification of cDNA ends; UAP: Universal Amplification Primer; AAP: Abridged Amplification Primer.

\section{Additional material}

Additional file 1: Sequence of Primers and DNA probes. Table S1 contains PCR primers, EMSA probe sequence and bisulfite sequencing primers.

\section{Acknowledgements}

We are grateful to Dr. Warner C. Greene for the NF- $\kappa$ B expression vector, Dr. R Fillmore for guidance with the ChIP assay, and Ms. R Cochran for technical assistance.

This work was supported by NIH grants R01HL077769 and P20MD002314030001 awarded to S.F Ofori-Acquah and AHA grant 0655377B (J.A. King).

\section{Author details}

${ }^{1}$ Center for Lung Biology, University of South Alabama, 307 N. University Boulevard, Mobile, AL 36688, USA. ${ }^{2}$ Center of Excellence in Healthy Communities, University of South Alabama, 307 N. University Boulevard, Mobile, AL 36688, USA. ${ }^{3}$ Aflac Cancer Center and Blood Disorders Service, Department of Pediatrics, Emory University School of Medicine, 2015 Uppergate Drive, Atlanta, GA 30322, USA. ${ }^{4}$ Mitchell Cancer Institute, University of South Alabama, 1660 Springhill Avenue, Mobile, AL 36604, USA.

Authors' contributions

JAK participated in the design of the studies and performed experiments. FT performed experiments and prepared the manuscript. FM, ZC, SC, HC, DA and LAS performed experiments. SFOA designed the study, analyzed data and wrote the manuscript. All authors read and approved the final manuscript.

\section{Competing interests}

The authors declare that they have no competing interests.

Received: 17 March 2010 Accepted: 7 October 2010

Published: 7 October 2010

\section{References}

1. Bruder SP, Ricalton NS, Boynton RE, Connolly TJ, Jaiswal N, Zaia J, Barry FP: Mesenchymal stem cell surface antigen SB-10 corresponds to activated leukocyte cell adhesion molecule and is involved in osteogenic differentiation. J Bone Miner Res 1998, 13:655-663. 
2. Bowen MA, Patel DD, Li X, Modrell B, Malacko AR, Wang WC, Marquardt $H$, Neubauer M, Pesando JM, Francke $U$, et al: Cloning, mapping, and characterization of activated leukocyte-cell adhesion molecule (ALCAM), a CD6 ligand. J Exp Med 1995, 181:2213-2220.

3. Burns FR, von Kannen S, Guy L, Raper JA, Kamholz J, Chang S: DM-GRASP, a novel immunoglobulin superfamily axonal surface protein that supports neurite extension. Neuron 1991, 7:209-220.

4. Kanki JP, Chang S, Kuwada JY: The molecular cloning and characterization of potential chick DM-GRASP homologs in zebrafish and mouse. $J$ Neurobiol 1994, 25:831-845.

5. Konno A, Ahn JS, Kitamura H, Hamilton MJ, Gebe JA, Aruffo A, Davis WC: Tissue distribution of CD6 and CD6 ligand in cattle: expression of the CD6 ligand (CD166) in the autonomic nervous system of cattle and the human. J Leukoc Biol 2001, 69:944-950.

6. Laessing U, Giordano S, Stecher B, Lottspeich F, Stuermer CA: Molecular characterization of fish neurolin: a growth-associated cell surface protein and member of the immunoglobulin superfamily in the fish retinotectal system with similarities to chick protein DM-GRASP/SC-1/BEN. Differentiation 1994, 56:21-29.

7. Paschke KA, Lottspeich F, Stuermer CA: Neurolin, a cell surface glycoprotein on growing retinal axons in the goldfish visual system, is reexpressed during retinal axonal regeneration. J Cell Biol 1992, 117:863-875

8. Peduzzi JD, Irwin MH, Geisert EE Jr: Distribution and characteristics of a 90 kDa protein, KG-CAM, in the rat CNS. Brain Res 1994, 640:296-307.

9. Pourquie O, Corbel C, Le Caer JP, Rossier J, Le Douarin NM: BEN, a surface glycoprotein of the immunoglobulin superfamily, is expressed in a variety of developing systems. Proc Natl Acad Sci USA 1992, 89:5261-5265.

10. Prince JT, Nishiyama A, Healy PA, Beasley L, Stallcup WB: Expression of the F84.1 glycoprotein in the spinal cord and cranial nerves of the developing rat. Brain Res Dev Brain Res 1992, 68:193-201.

11. Stephan JP, Bald L, Roberts PE, Lee J, Gu Q, Mather JP: Distribution and function of the adhesion molecule BEN during rat development. Dev Biol 1999, 212:264-277.

12. Tanaka H, Matsui T, Agata A, Tomura M, Kubota I, McFarland KC, Kohr B, Lee A, Phillips HS, Shelton DL: Molecular cloning and expression of a novel adhesion molecule, SC1. Neuron 1991, 7:535-545.

13. van Kempen LC, Nelissen JM, Degen WG, Torensma R, Weidle UH, Bloemers HP, Figdor CG, Swart GW: Molecular basis for the homophilic activated leukocyte cell adhesion molecule (ALCAM)-ALCAM interaction. J Biol Chem 2001, 276:25783-25790.

14. Degen WG, van Kempen LC, Gijzen EG, van Groningen JJ, van Kooyk Y, Bloemers HP, Swart GW: MEMD, a new cell adhesion molecule in metastasizing human melanoma cell lines, is identical to ALCAM (activated leukocyte cell adhesion molecule). Am J Pathol 1998, 152:805-813

15. van Kempen LC, van den Oord JJ, van Muijen GN, Weidle UH, Bloemers HP, Swart GW: Activated leukocyte cell adhesion molecule/CD166, a marker of tumor progression in primary malignant melanoma of the skin. Am J Pathol 2000, 156:769-774.

16. Zheng $X$, Ding W, Xie L, Chen Z: Expression and significance of activated leukocyte cell adhesion molecule in prostatic intraepithelial neoplasia and adenocarcinoma. Zhonghua Nan Ke Xue 2004, 10:265-268.

17. Kristiansen G, Pilarsky C, Wissmann C, Stephan C, Weissbach L, Loy V, Loening S, Dietel M, Rosenthal A: ALCAM/CD166 is up-regulated in lowgrade prostate cancer and progressively lost in high-grade lesions. Prostate 2003, 54:34-43.

18. Verma A, Shukla NK, Deo SV, Gupta SD, Ralhan R: MEMD/ALCAM: a potential marker for tumor invasion and nodal metastasis in esophageal squamous cell carcinoma. Oncology 2005, 68:462-470.

19. Weichert W, Knosel T, Bellach J, Dietel M, Kristiansen G: ALCAM/CD166 is overexpressed in colorectal carcinoma and correlates with shortened patient survival. J Clin Pathol 2004, 57:1160-1164.

20. Tomita K, van Bokhoven A, Jansen CFJ, Kiemeney LA, Karthaus HFM, Vriesema J, Bussemakers MJG, Witjes JA, Schalken JA: Activated leukocyte cell adhesion molecule (ALCAM) expression is associated with a poor prognosis for bladder cancer patients. UroOncology 2003, 3:121-129.

21. Kahlert C, Weber H, Mogler C, Bergmann F, Schirmacher P, Kenngott HG, Matterne U, Mollberg N, Rahbari NN, Hinz U, et al: Increased expression of ALCAM/CD166 in pancreatic cancer is an independent prognostic marker for poor survival and early tumour relapse. Br J Cancer 2009, 101:457-464.

22. Ofori-Acquah SF, King JA: Activated leukocyte cell adhesion molecule: a new paradox in cancer. Transl Res 2008, 151:122-128.

23. King JA, Ofori-Acquah SF, Stevens T, Al-Mehdi AB, Fodstad O, Jiang WG: Activated leukocyte cell adhesion molecule in breast cancer: prognostic indicator. Breast Cancer Res 2004, 6:R478-487.

24. Davies SR, Dent C, Watkins G, King JA, Mokbel K, Jiang WG: Expression of the cell to cell adhesion molecule, ALCAM, in breast cancer patients and the potential link with skeletal metastasis. Oncol Rep 2008, 19:555-561.

25. Jezierska A, Olszewski WP, Pietruszkiewicz J, Olszewski W, Matysiak W, Motyl T: Activated Leukocyte Cell Adhesion Molecule (ALCAM) is associated with suppression of breast cancer cells invasion. Med Sci Monit 2006, 12:BR245-256.

26. Burkhardt M, Mayordomo E, Winzer KJ, Fritzsche F, Gansukh T, Pahl S, Weichert W, Denkert C, Guski H, Dietel M, Kristiansen G: Cytoplasmic overexpression of ALCAM is prognostic of disease progression in breast cancer. J Clin Pathol 2006, 59:403-409.

27. Kilic E, Milde-Langosch K, Muller V, Wirtz R, Ihnen M: Expression of activated leukocyte cell adhesion molecule in breast cancer. Predictability of the response to taxane-free chemotherapy. Pathologe 2008, 29(Suppl 2):347-352.

28. Ihnen M, Muller V, Wirtz RM, Schroder C, Krenkel S, Witzel I, Lisboa BW, Janicke F, Milde-Langosch K: Predictive impact of activated leukocyte cell adhesion molecule (ALCAM/CD166) in breast cancer. Breast Cancer Res Treat 2008, 112:419-427.

29. Glaves D, Huben RP, Weiss L: Haematogenous dissemination of cells from human renal adenocarcinomas. $\mathrm{Br} J$ Cancer 1988, 57:32-35.

30. Al-Mehdi AB, Tozawa K, Fisher A, Shientag L, Lee A, Muschel R: Intravascular origin of metastasis from the proliferation of endotheliumattached tumor cells: a new model for metastasis. Nature Med 2000 6:100-101

31. Wong CW, Song C, Grimes MM, Fu W, Dewhirst MW, Muschel RJ, AlMehdi $A B$ : Intravascular location of breast cancer cells after spontaneous metastasis to the lung. Am J Pathol 2002, 161:749-753.

32. Zhang G, Slaughter C, Humphries EH: v-rel Induces ectopic expression of an adhesion molecule, DM-GRASP, during B-lymphoma development. Mol Cell Biol 1995, 15:1806-1816.

33. Begg CB, Orlow I, Hummer AJ, Armstrong BK, Kricker A, Marrett LD, Millikan RC, Gruber SB, Anton-Culver $H$, Zanetti $R$, et al: Lifetime risk of melanoma in CDKN2A mutation carriers in a population-based sample. $J$ Natl Cancer Inst 2005, 97:1507-1515.

34. Borner C, Schlagbauer Wadl H, Fellay I, Selzer E, Polterauer P, Jansen B: Mutated $\mathrm{N}$-ras upregulates $\mathrm{BCl}-2$ in human melanoma in vitro and in SCID mice. Melanoma Res 1999, 9:347-350

35. Celebi JT, Shendrik I, Silvers DN, Peacocke M: Identification of PTEN mutations in metastatic melanoma specimens. J Med Genet 2000, 37:653-657.

36. Davies H, Bignell GR, Cox C, Stephens P, Edkins S, Clegg S, Teague J, Woffendin H, Garnett MJ, Bottomley W, et al: Mutations of the BRAF gene in human cancer. Nature 2002, 417:949-954.

37. Ikeda K, Quertermous T: Molecular isolation and characterization of a soluble isoform of activated leukocyte cell adhesion molecule that modulates endothelial cell function. J Biol Chem 2004, 279:55315-55323.

38. Issa JP, Garcia-Manero G, Giles FJ, Mannari R, Thomas D, Faderl S, Bayar E, Lyons J, Rosenfeld CS, Cortes J, Kantarjian HM: Phase 1 study of low-dose prolonged exposure schedules of the hypomethylating agent 5-aza-2'deoxycytidine (decitabine) in hematopoietic malignancies. Blood 2004, 103:1635-1640.

39. Seniski GG, Camargo AA, lerardi DF, Ramos EA, Grochoski M, Ribeiro ES, Cavalli IJ, Pedrosa FO, de Souza EM, Zanata SM, et al: ADAM33 gene silencing by promoter hypermethylation as a molecular marker in breast invasive lobular carcinoma. BMC Cancer 2009, 9:80.

40. Wei M, Grushko TA, Dignam J, Hagos F, Nanda R, Sveen L, Xu J, Fackenthal J, Tretiakova M, Das S, Olopade OI: BRCA1 promoter methylation in sporadic breast cancer is associated with reduced BRCA1 copy number and chromosome 17 aneusomy. Cancer Res 2005, 65:10692-10699.

41. Jezierska A, Matysiak W, Motyl T: ALCAM/CD166 protects breast cancer cells against apoptosis and autophagy. Med Sci Monit 2006, 12:BR263-273. 
42. Jezierska A, Olszewski WP, Pietruszkiewicz J, Olszewski W, Matysiak W, Motyl T: Activated Leukocyte Cell Adhesion Molecule (ALCAM) is associated with suppression of breast cancer cells invasion. Med Sci Monit 2006, 12:BR245-256.

43. Davies $S$, Jiang WG: ALCAM, activated leukocyte cell adhesion molecule, influences the aggressive nature of breast cancer cells, a potential connection to bone metastasis. Anticancer Res 2010, 30:1163-1168.

44. Ihnen M, Wirtz RM, Kalogeras KT, Milde-Langosch K, Schmidt M, Witzel I, Eleftheraki AG, Papadimitriou C, Janicke F, Briassoulis E, et al: Combination of osteopontin and activated leukocyte cell adhesion molecule as potent prognostic discriminators in HER2- and ER-negative breast cancer. Br J Cancer 2010.

45. Kulasingam $V$, Zheng $Y$, Soosaipillai $A$, Leon AE, Gion M, Diamandis EP Activated leukocyte cell adhesion molecule: a novel biomarker for breast cancer. Int I Cancer 2009, 125:9-14.

46. De Leeuw WJ, Berx G, Vos CB, Peterse JL, Van de Vijver MJ, Litvinov S, Van Roy F, Cornelisse CJ, Cleton-Jansen AM: Simultaneous loss of E-cadherin and catenins in invasive lobular breast cancer and lobular carcinoma in situ. J Pathol 1997, 183:404-411.

47. Masedunskas A, King JA, Tan F, Cochran R, Stevens T, Sviridov D, OforiAcquah SF: Activated leukocyte cell adhesion molecule is a component of the endothelial junction involved in transendothelial monocyte migration. FEBS Lett 2006, 580:2637-2645.

48. Fillmore RA, Mitra A, Xi Y, Ju J, Scammell J, Shevde LA, Samant RS: Nmi (NMyc interactor) inhibits Wnt/beta-catenin signaling and retards tumor growth. Int J Cancer 2009, 125:556-564.

49. Mitra A, Fillmore RA, Metge BJ, Rajesh M, Xi Y, King J, Ju J, Pannell L, Shevde LA, Samant RS: Large isoform of MRJ (DNAJB6) reduces malignant activity of breast cancer. Breast Cancer Res 2008, 10:R22.

50. Shevde LA, Samant RS, Paik JC, Metge BJ, Chambers AF, Casey G, Frost AR, Welch DR: Osteopontin knockdown suppresses tumorigenicity of human metastatic breast carcinoma, MDA-MB-435. Clin Exp Metastasis 2006, 23:123-133.

51. Samant RS, Seraj MJ, Saunders MM, Sakamaki TS, Shevde LA, Harms JF, Leonard TO, Goldberg SF, Budgeon L, Meehan WJ, et al: Analysis of mechanisms underlying BRMS1 suppression of metastasis. Clin Exp Metastasis 2000, 18:683-693.

52. Chetham PM, Babal P, Bridges JP, Moore TM, Stevens T: Segmental regulation of pulmonary vascular permeability by store-operated $\mathrm{Ca} 2+$ entry. Am J Physiol 1999, 276:L41-50.

53. Alvarez DF, King JA, Weber D, Addison E, Liedtke W, Townsley MI: Transient receptor potential vanilloid 4-mediated disruption of the alveolar septal barrier: a novel mechanism of acute lung injury. Circ Res 2006, 99:988-995.

doi:10.1186/1476-4598-9-266

Cite this article as: King et al: Mechanisms of transcriptional regulation and prognostic significance of activated leukocyte cell adhesion molecule in cancer. Molecular Cancer 2010 9:266.

\section{Submit your next manuscript to BioMed Central and take full advantage of:}

- Convenient online submission

- Thorough peer review

- No space constraints or color figure charges

- Immediate publication on acceptance

- Inclusion in PubMed, CAS, Scopus and Google Scholar

- Research which is freely available for redistribution

Submit your manuscript at www.biomedcentral.com/submit 